\title{
The production and characterisation of rabbit antiserum and murine monoclonal antibodies to Haemophilus ducreyi
}

\author{
GEETA Y. FINN, Q. NAJMA KARIM* and C. S. F. EASMON
}

Department of Medical Microbiology, Wright-Fleming Institute, St Mary's Hospital Medical School, Praed Street, London W2 1PG

\begin{abstract}
Summary. Rabbit antiserum and murine monoclonal antibodies were raised against a strain of Haemophilus ducreyi. The antiserum gave high immunofluorescence titres and strong dot blot reactions with all $H$. ducreyi strains tested and the only cross reaction was with Bordetella pertussis. Three monoclonal antibodies, all of isotype IgG2a, also gave high immunofluorescence titres with $H$. ducreyi but did not cross react with any other species tested. Immunoblotting showed the monoclonal antibodies to react with a single polypeptide band of mol. wt 29000 in the outermembrane fraction of $H$. ducreyi. These antibodies have potential for use as diagnostic reagents and for investigating the pathogenicity of $H$. ducreyi.
\end{abstract}

\section{Introduction}

Haemophilus ducreyi is the causative organism of the sexually transmitted disease chancroid, the commonest cause of genital ulcers in the tropics. However, in recent years there have been increasing numbers of outbreaks in the more temperate regions of Europe and North America. ${ }^{1,2}$

$H$. ducreyi is a fastidious organism and, despite improved culture methods, isolation rates from genital ulcers and buboes can still be lower than $60 \%$. In many countries where facilities for culture are often not available, diagnosis of chancroid continues to be based on clinical features and the exclusion of other causes of genital ulcers. This form of diagnosis is prone to error. ${ }^{3}$ Direct microscopy of gram-stained smears is also insensitive; the typical "shoal of fish" morphology of $H$. ducreyi is often not seen, and other contaminating gram-negative bacilli may look similar.,

To overcome these problems, several groups of workers have attempted to develop immunological methods of diagnosis. Denys et al. ${ }^{5}$ raised an antiserum for use in an immunofluorescence assay for $\boldsymbol{H}$. ducreyi. This antiserum, however, had to be absorbed extensively with other Haemophilus spp. to eliminate cross-reactivity. Even after absorption it gave a moderate fluorescence with several other Haemophilus spp., in particular $H$. parainfluenzae. In 1984, Hansen and Loftus ${ }^{6}$ raised monoclonal

Received 27 July 1989; revised version accepted 9 Oct. 1989. *Correspondence should be sent to Dr Q. N. Karim. antibodies (MAbs) against $H$. ducreyi. By radioimmunoassay, these MAbs were shown to detect $H$. ducreyi in smears from ulcers caused by this pathogen in experimentally-infected animals.

Clearly there is a need for a simple, inexpensive, sensitive immunodiagnostic test, such as immunofluorescence, which is specific for strains of $H$. ducreyi from different areas where chancroid is prevalent. In this paper we describe the production and evaluation of a rabbit antiserum and three mouse MAbs with these aims in mind.

\section{Materials and methods}

\section{Bacterial strains}

Sixty-six strains of $H$. ducreyi isolated from patients with chancroid were examined. These included isolates from Canada (3 strains), the USA (3), France (2), England (9), Thailand (11), Kenya (15), the Gambia (4) and South Africa (13). The source of six further strains was not known. $H$. ducreyi strain 3138 , kindly provided by Professor P. Piot, was used for immunisation of rabbits and mice.

Other bacteria used in this study were either taxonomically related to $H$. ducreyi or were species commonly isolated from the genital tract. These included $H$. influenzae (10 strains), H.parainfluenzae (4), H.aphrophilus (3), $H$. paraphrophilus (4), $H$. parahaemolyticus (3), $H$. aegyptius (3), Gardnerella vaginalis (24), Bordetella pertussis (1), Pasteurella pneumotropica (1), P. ureae (1), Neisseria gonorrhoeae (30), Mobiluncus holmseii (3), M. curtisii (2), Treponema pallidum (1), Lactobacillus acidophilus (1), Bacteroides fragilis (1), B. melaninogenicus (1), $\beta$-haemoly- 
tic streptococcus group $A(2)$, group $B(3)$, and group $D$ (2), Escherichia coli (1), Klebsiella pneumoniae (1), Proteus mirabilis (1), Pseudomonas aeruginosa (1) and Clostridium sordellii (1).

\section{Growth}

$H$. ducreyi was grown on the medium described by Hammond et al.: ${ }^{7}$ Mueller Hinton Agar (BBL Microbiology) containing chocolatised horse blood (Oxoid) $5 \% \mathrm{v} / \mathrm{v}$ fetal calf serum (Gibco) $5 \% \mathrm{v} / \mathrm{v}$ and IsoVitalex $2 \% \mathrm{v} / \mathrm{v}$. Vancomycin hydrochloride (Lilly) $3 \mathrm{mg} / \mathrm{L}$ was added to make the medium selective for use in the initial isolation of clinical strains. The inoculated plates were incubated at $33^{\circ} \mathrm{C}$ in the presence of $\mathrm{CO}_{2} 10 \%$ and moisture for $48 \mathrm{~h}$.

Other bacteria used in this study were cultured on appropriate solid media with the exception of $T$. pallidum for which antigen-coated slides normally used for fluorescent treponemal serology were used.

\section{Production of rabbit antiserum}

Antiserum to $H$. ducreyi was raised in New Zealand White rabbits each weighing $c .2 .5 \mathrm{~kg}$. Rabbits were bled to obtain pre-immunisation serum which was pooled. A 48-h growth of $\boldsymbol{H}$. ducreyi strain 3138 on Mueller Hinton Agar was harvested and washed three times in saline for injection (B.P.). Rabbits were immunised with $4 \times$ $10^{6} \mathrm{cfu}$ of $H$. ducreyi suspended in $0.4 \mathrm{ml}$ of Freunds incomplete adjuvant and given as four subcutaneous injections into separate sites on the back. Fourteen days later the rabbits were given an intramuscular injection of $2 \times 10^{6} \mathrm{cfu}$ in $0.2 \mathrm{ml}$ of saline (B.P.). On days 15,16 and 17 they were given intravenous injections of $5 \times 10^{6}, 10^{7}$ and $2 \times 10^{7} \mathrm{cfu}$ of $H$. ducreyi respectively in $0.5 \mathrm{ml}, 1.0 \mathrm{ml}$ and $2.0 \mathrm{ml}$ of saline. On day 26 rabbits were bled and the serum was pooled, divided into $1 \cdot 0-\mathrm{ml}$ volumes and stored at $-70^{\circ} \mathrm{C}$.

\section{Production of monoclonal antibodies}

Eight-week-old BALB/C mice were immunised subcutaneously with $2 \times 10^{6}$ cfu of $H$. ducreyi strain 3138 in $0.2 \mathrm{ml}$ of saline (B.P.). Twenty-eight days later, mice were given a further $2 \times 10^{6} \mathrm{cfu}$ intraperitoneally in $0.2 \mathrm{ml}$ of saline followed on day 31 with a similar dose and volume of $H$. ducreyi suspension injected intravenously. Three days later the mouse spleens were removed for fusion with the NSO myeloma cell line by the standard technique of Kohler and Milstein. ${ }^{8}$

Culture supernatant fluids of the resultant hybrids were screened for the presence of antibody to $H$. ducreyi by an indirect immunofluorescence method described in detail below. Antibody-positive hybridomas were isolated and cloned by passage through five limiting dilution stages. Supernates were tested for the production of antibody at each stage of cloning.

Three cell lines secreting highly reactive antibody were expanded into a series of $75 \mathrm{~cm}^{3}$ tissue-culture flasks (Costar) to produce $1 \mathrm{~L}$ of hybridoma supernate in maximum growth medium. This was centrifuged at $1200 \mathrm{~g}$ for $10 \mathrm{~min}$ to remove cells. The clear supernate was stored at $4^{\circ} \mathrm{C}$ until further use.

\section{Purification and concentration of monoclonal antibodies}

One gram of protein A-sepharose (Sigma) was held in

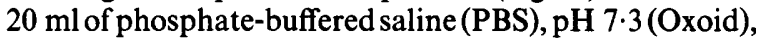
for $2 \mathrm{~h}$ at room temperature, to allow it to swell, then packed into a small chromatography column. With a flow rate of $1-2 \mathrm{ml} / \mathrm{min}$ the column was washed with $0.1 \mathrm{M}$ citrate buffer, $\mathrm{pH} 3 \cdot 0$, then equilibrated for $2 \mathrm{~h}$ with $0 \cdot 1 \mathrm{M}$ phosphate buffer, $\mathrm{pH} 8 \cdot 0$. The maximum growth medium supernate containing the MAb was mixed with one tenth of its volume of $0 \cdot 1 \mathrm{M}$ Tris- $\mathrm{HCl}, \mathrm{pH} 8 \cdot 2$. The mixture was applied to the column in the cold (flow rate $1.0 \mathrm{ml} / \mathrm{min}$ ), then washed through with $30 \mathrm{ml} 0 \cdot 1 \mathrm{M}$ phosphate buffer, $\mathrm{pH} 8.0$. The bound immunoglobulin was eluted from the protein A with $0 \cdot 1 \mathrm{M}$ citrate buffer, $\mathrm{pH} 4 \cdot 5$.

One-ml fractions of eluate were collected. To minimise the denaturation of the antibody, $0.2 \mathrm{ml}$ of $1.0 \mathrm{M}$ Tris$\mathrm{HCl}, \mathrm{pH} \mathrm{9.0,} \mathrm{was} \mathrm{added} \mathrm{to} \mathrm{the} \mathrm{tubes} \mathrm{before} \mathrm{collection} \mathrm{of}$ the fractions. The antibody-containing fractions were determined by spectrophotometry at a wavelength of $280 \mathrm{~nm}$. The peak fractions were pooled and stored at $-20^{\circ} \mathrm{C}$ in $0.5-\mathrm{ml}$ volumes.

\section{Preparation of outer membranes}

Outer membranes of $\boldsymbol{H}$. ducreyi were prepared according to the procedure described by Barenkamp et al..$^{9}$ and modified by Odumeru et al. ${ }^{10} \mathrm{~A}$ 24-h growth on agar was

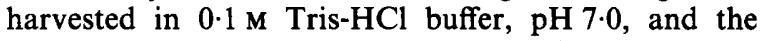
organisms were collected by centrifugation at $10000 \mathrm{~g}$ for $20 \mathrm{~min}$. The organisms were suspended in $10 \mathrm{ml}$ of

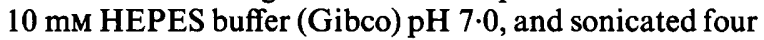
times for $20 \mathrm{~s}$ while cooling in an ice bath. The whole-cell sonicate was centrifuged at $10000 \mathrm{~g}$ for $20 \mathrm{~min}$ to remove intact cells and the supernate was then centrifuged at $100000 \mathrm{~g}$ for $60 \mathrm{~min}$. The outer-membrane fraction was obtained by suspending the pellet in HEPES buffer, $\mathrm{pH} 7 \cdot 4$, and extracting with sodium lauryl sarcosinate $2 \% \mathrm{w} / \mathrm{v}$.

Protein content was determined by the method of Lowry et al. ${ }^{11}$ with bovine serum albumin as the standard.

\section{Indirect immunofluorescence}

The immunising strain of $H$. ducreyi, strain 3138, was used to screen the rabbit antiserum and the hybridoma supernates for specific antibody. Antigen-coated multispot slides were prepared with overnight agar-plate cultures of $H$. ducreyi washed and re-suspended in PBS to a concentration of $5 \times 10^{7} \mathrm{cfu} / \mathrm{ml}$. The wells were filled with $30 \mu \mathrm{l}$ of this suspension and allowed to dry in air. Slides were fixed by immersion in absolute methanol for 
$10 \mathrm{~min}$. They were rinsed twice in PBS, once in distilled water, dried in air and stored in slide boxes at $-70^{\circ}$. Slides were used within 1 month of freezing. A single batch of slides was prepared for use with polyclonal and monoclonal reagents respectively.

The antigen-coated slides were thawed when required. A $20 \mu \mathrm{l}$ volume of diluted antiserum, hybridoma supernate, or a 1 in 20 dilution of purified MAb was added to each well. After incubation for $30-60 \mathrm{~min}$ at $37^{\circ} \mathrm{C}$ in a humid atmosphere, the slides were washed twice in PBS, once in distilled water and dried in air. They were then stained with a fluorescein-conjugated antibody to mouse immunoglobulin (Dakopatts) for $30-60 \mathrm{~min}$ at $37^{\circ} \mathrm{C}$ in a humid atmosphere. The conjugate was used at a dilution of 1 in 10 for screening and at a dilution of 1 in 35 for sensitivity and specificity testing. Slides were finally washed in PBS, counterstained in Evan's Blue $0.1 \% \mathrm{w} / \mathrm{v}$ for $5 \mathrm{~min}$, washed in distilled water and dried in air. Slides were examined under the oil immersion lens of a fluorescence microscope and reactions scored visibly as follows: strong +++ , moderate ++ and weak + fluorescence. $\mathrm{A}++$ reaction was taken as positive.

\section{Dot immunoblotting}

The preparation of the whole-cell antigens and the methods adopted in this study have been described by Ison et $a l .{ }^{15}$ The sensitivity and specificity of the antiserum was tested with $H$. ducreyi strain 3138 and nine other clinical isolates and against $H$. influenzae types a-f, $H$. aphrophilus, $H$. parainfluenzae, $G$. vaginalis, $L$. acidophilus, $B$. pertussis, $N$. gonorrhoeae, $P$. pneumotropica and $P$. ureae. The antiserum was used at a dilution of 1 in 7000 and the anti-rabbit immunoglobulin linked to alkaline phosphatase (Dakopatts) was used at a dilution of 1 in 3000. The colour intensity of the developed blots was scored visibly as described above. $\mathrm{A}++$ reaction was taken as positive.

\section{Determination of immunoglobulin class}

The immunoglobulin class of the MAbs was determined by a capture enzyme-linked immunoglobulin assay with sheep-antimouse IgG2a (Serotec), and goat-antimouse IgG1, IgG2b, IgG3 and IgM (Sigma). The binding of the MAbs to the specific typing antisera was determined by absorbance readings at a wavelength of $405 \mathrm{~nm}$.

\section{Electrophoresis and immunoblotting}

The protein concentration of the suspension was estimated ${ }^{11}$ and adjusted to $2 \mathrm{mg} / \mathrm{ml}$. The suspension was diluted in double-strength sampling buffer (bromophenol blue $0.1 \% \mathrm{w} / \mathrm{v}$, sodium dodecyl sulphate $2 \% \mathrm{w} / \mathrm{v}, 0.1 \mathrm{M}$ Tris- $\mathrm{HCl}, \mathrm{pH} 6 \cdot 8,8 \% \mathrm{w} / \mathrm{v}$ and glycerol $10 \% \mathrm{w} / \mathrm{v})$. Samples were prepared in the presence or absence of $0.1 \mathrm{M}$ dithiothreitol (DTT) (Sigma) and solubilised at $100^{\circ} \mathrm{C}$ or $37^{\circ} \mathrm{C}$ for $10 \mathrm{~min}$.
Whole-cell lysates and outer-membrane protein fractions were separated by sodium dodecyl sulphatepolyacrylamide gel electrophoresis (SDS-PAGE) as described by Laemmli, ${ }^{12}$ with a $10 \%$ separating gel and a $5 \%$ stacking gel in a Protean II apparatus (Bio-Rad). Samples containing approximately $40 \mu \mathrm{g}$ of protein were loaded on to the gel and run for $2 \mathrm{~h}$ at $30 \mathrm{~mA}$ gel.

Proteins were then transferred to nitrocellulose $(\mathrm{Hy}-$ bond $\mathrm{C}$, Amersham) electrophoretically in a buffer containing $20 \mathrm{mM}$ Tris, $150 \mathrm{mM}$ glycine and methanol $20 \%(\mathrm{v} / \mathrm{v})$ in a Transblot apparatus (Bio-Rad Laboratories) with a current of $200 \mathrm{~mA}$ for $2 \mathrm{~h}^{13,14}$ After transfer, the non-specific binding sites were blocked with bovine serum albumin $4 \% \mathrm{w} / \mathrm{v}$ in washing buffer $(0.15 \mathrm{~mm}$ sodium chloride, $10 \mathrm{~mm}$ Tris, $\mathrm{pH} \mathrm{7 \cdot 4)}$ for $3 \mathrm{~h}$. Membranes were then developed by the method described by Ison $e t$ $a l .{ }^{15}$ with rabbit antiserum at a dilution of 1 in 7000 , the MAbs at 1 in 100000 and the antispecies immunoglobulin linked to alkaline phosphatase (Dakopatts) at 1 in 3000 .

\section{Results}

\section{Sensitivity and specificity of the rabbit antiserum}

The activity of pooled rabbit antiserum against $H$. ducreyi strains is shown in table I. Most strains gave an indirect immunofluorescence titre of 640 but some were lower, the lowest being 160 with strain 149. In contrast only one of the other species tested had a titre of more than 20 . This was the $B$. pertussis strain which had a titre of 80 .

The dot-immunoblotting results matched those obtained with immunofluorescence. Since the epitopes concerned may not be equally well exposed on all strains of $H$. ducreyi, sensitivity testing was performed at the optimal dilution for the immunising strain, 1 in 7000, as well as at 1 in 2000 . The pooled rabbit antiserum produced a strong reaction with all strains of $H$. ducreyi tested at both dilutions.

Table I. Reactivity of rabbit antiserum against $H$. ducreyi as measured by indirect immunofluorescence and dot blotting

\begin{tabular}{|c|c|c|c|}
\hline \multicolumn{2}{|c|}{ H. ducreyi } & \multirow{2}{*}{$\begin{array}{c}\text { Immuno- } \\
\text { fluorescence } \\
\text { titre }\end{array}$} & \multirow{2}{*}{$\begin{array}{l}\text { Dot-blotting* } \\
\text { reaction }\end{array}$} \\
\hline Strain & Origin & & \\
\hline $\begin{array}{c}3138 \\
\text { SP } 149 \\
3229 \\
3230 \\
6 \text { other isolates }\end{array}$ & $\begin{array}{l}\text { Kenya } \\
\text { Unknown } \\
\text { Thailand } \\
\text { Thailand } \\
\text { Canada } \\
\text { France } \\
\text { Malaysia } \\
\text { Kenya }\end{array}$ & $\begin{array}{r}1280 \\
160 \\
320 \\
320\end{array}$ & $\begin{array}{l}+++ \\
+++ \\
+++ \\
+++\end{array}$ \\
\hline
\end{tabular}

*Measured with antiserum at a dilution of 1 in 7000 . 
At the 1 in 2000 dilution, cross reactions were seen with other species. However, at a dilution of 1 in 7000 , only $B$. pertussis gave a positive cross reaction (fig. 1).

\section{Sensitivity and specificity of monoclonal antibodies}

Of the 96 wells on which fusions were carried out, $58(60 \%)$ contained hybrids. In $25(43 \%)$ of the 58 wells, specific $H$. ducreyi-binding antibody was detected. Many clones subsequently stopped producing antibody. Three MAbs, A4, B11 and D1, were selected for further analysis as described below.

All three antibodies were of isotype IgG2a. Their titres before and after purification were determined by immunofluorescence, dot-blotting and immunoblotting applied to serial dilutions of supernate or antibody. Protein A-sepharose column purification produced a 20 -fold increase in antibody titres with all three systems: with immunofluorescence from 32 to 640, with dot-blot and immunoblot from 10000 to 200000 . Since the project was perceived with the development of an immunofluorescence system in mind, this technique only was used in sensitivity and specificity testing of the MAbs.

All of the 15 strains of $H$. ducreyi tested initially gave good immunofluorescence titres with the three MAbs (table II). The remaining 51 strains of $H$. ducreyi were tested with the MAbs at a dilution of 1 in 300 . All gave strong reactions. There was no
Table II. Sensitivity of three MAbs against $H$. ducreyi measured by indirect immunofluorescence

\begin{tabular}{|c|c|c|c|c|}
\hline \multicolumn{2}{|c|}{ H. ducreyi } & \multicolumn{3}{|c|}{$\begin{array}{l}\text { Immunofluorescence titre with } \\
\text { MAbs }\end{array}$} \\
\hline Strain & Origin & A4 & B11 & D1 \\
\hline $\begin{array}{r}3138 \\
\text { GU42 } \\
9926 \\
36-F-2 \\
\text { SP } 149 \\
2677 \\
9 \text { other } \\
\text { isolates }\end{array}$ & $\begin{array}{l}\text { Kenya } \\
\text { Gambia } \\
\text { Kenya } \\
\text { France } \\
\text { Unknown } \\
\text { Kenya } \\
\text { Thailand } \\
\text { France } \\
\text { Canada and } \\
\text { S. Africa }\end{array}$ & $\begin{array}{l}640 \\
640 \\
640 \\
320 \\
640 \\
320\end{array}$ & $\begin{array}{r}640 \\
2048 \\
320 \\
320 \\
640 \\
640\end{array}$ & $\begin{array}{r}640 \\
640 \\
640 \\
320 \\
1024 \\
640\end{array}$ \\
\hline
\end{tabular}

cross reaction with any other species including $\boldsymbol{B}$. pertussis.

\section{Immunoblotting}

The immunoblot of the rabbit antiserum against whole-cell lysates of $H$. ducreyi showed a number of bands with mol. wts in the range $25000-65000$. $B$. pertussis, the only other organism to show any appreciable reaction with this antiserum, produced a number of bands of similar size to those seen with H. ducreyi; none was strong.

In contrast, the three MAbs reacted with only a

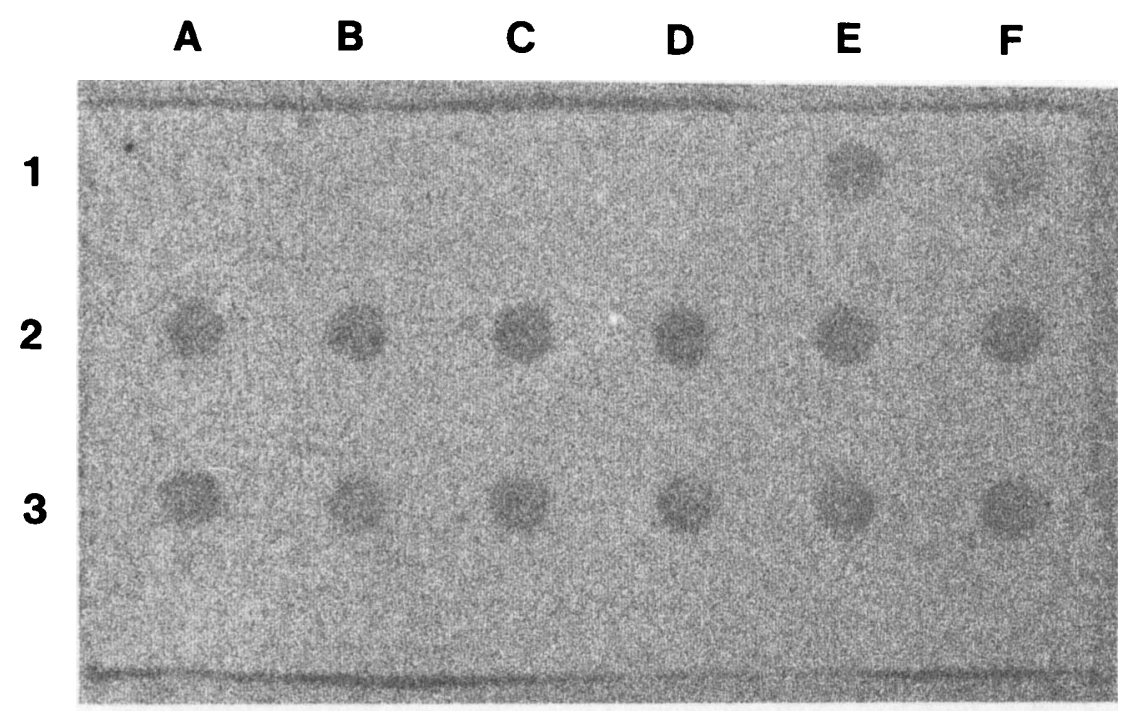

Fig. 1. Sensitivity and specificity of rabbit antiserum (dilution 1 in 7000) measured by dot immunoblotting. 1(A) N. gonorrhoeae; (B) G. vaginalis (10915); (C) L. acidophilus; (D) H. influenzae; (E) and (F) B. pertussis; 2 (A)-(F) H. ducreyi, six strains; 2(C) H. ducreyi 3138 (immunising strain); 3(A)-(F) H. ducreyi, six strains. 


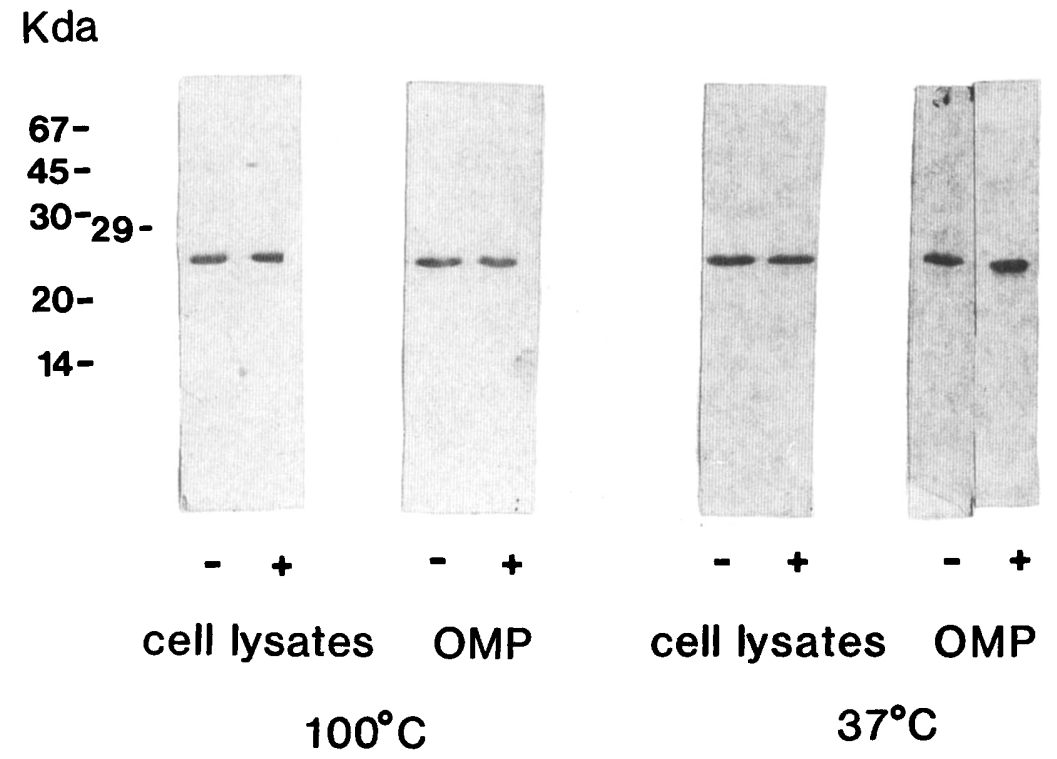

Fig. 2. Western blot of whole-cell lysates and outer-membrane protein (OMP) preparations of $H$. ducreyi strain 3138 with MAb A4. Samples were prepared in the presence $(+)$ or absence $(-)$ of dithiothreitol and solubilised at $100^{\circ} \mathrm{C}$ or $37^{\circ} \mathrm{C}$.

single band of mol. wt 29000 (fig. 2). This band was present in the whole-cell lysates and outermembrane protein fractions of $H$. ducreyi 3138 and three other strains tested. The bands stained with Coomassie blue and amido black (not shown) suggesting that they were polypeptides. Neither varying the solubilisation temperature nor treatment with DTT produced any effect on the reactivity of the epitope(s) with the MAbs (fig. 2).

\section{Discussion}

The primary aim of this project was to produce polyclonal and monoclonal reagents for possible use in a specific test for identifying $H$. ducreyi directly from clinical material. There is a range of immunoassays in which such reagents can be used, including agglutination and various solid phase immunoassays. We chose to concentrate initially on indirect immunofluorescence. This is a simple rapid technique suitable for use in developing countries where diagnostic facilities are limited. Clinical smears can be fixed easily and transported to a central reference laboratory for examination.

There is good precedent for this approach with another sexually-transmitted pathogen, Chlamydia trachomatis. Direct microscopy for chlamydia in genital or ocular samples is insensitive, and culture is relatively complex and time-consuming. The introduction of MAbs in immunofluorescence tests applied to clinical matter has produced a sensitive and rapid diagnostic test. ${ }^{16}$ With Neisseria gonorrhoeae, although MAbs are useful for identification, their application to direct clinical material is less well established. ${ }^{17}$

The rabbit antiserum which we raised against $H$. ducreyi reacted with several polypeptide-associated epitopes, but in contrast to the experience of Denys et al..$^{5}$ gave few cross reactions that could not be eliminated by further dilution. The exception was with $B$. pertussis. While this cross reaction is unlikely to present any practical difficulties, it merits further investigation.

MAbs have two main advantages over conventional antisera - their high degree of specificity and their consistency. However, this specificity, associated with recognition of a single epitope, means that individual MAbs may not necessarily be as sensitive as polyclonal antisera in detecting organisms. The three MAbs we selected for further study apparently detected the same outer-membrane polypeptide and were of the same isotope. They may well recognise the same epitope, although this would need to be investigated by inhibition studies. They are all highly specific for $H$. ducreyi, work well in immunofluorescence and to date the clones have continued to produce antibody satisfactorily in in-vitro culture.

Both the MAbs and the polyclonal antiserum appear promising as reagents for identifying $H$. 
ducreyi. Odumeru et al. ${ }^{10}$ have shown that the protein profiles of $H$. ducreyi, as assessed by SDSPAGE, are useful in subtyping within the species. At least seven subtypes have been identified based on their outer-membrane protein profiles. Our antibodies were found to react with strains of $H$. ducreyi from each of the seven subtypes. While our first aim was to use immunofluorescence, the results of the dot-blotting and immunoblotting assays suggest that they could be used in other solid phase immunoassays. Latex or co-agglutination systems too may be relevant.

Chancroid is the most common cause of genital ulceration in tropical areas. In sub-Saharan Africa, genital ulceration is linked to susceptibility to and

\section{REFERENCES}

1. Hammond G W, Slutchuk M, Scatliff M, Sherman E, Wilt J C, Ronald A R, Epidemiologic, clinical, laboratory, and therapeutic features of an urban outbreak of chancroid in North America. Rev Infect Dis 1980; 2: 867-879.

2. Lykke-Olesen L, Larsen L, Pedersen T G, Gaarsley K. Epidemic of chancroid in Greenland 1978-1979. Lancet $1979 ; 1: 654-655$.

3. Chapel T A, Brown W J, Jeffries C D, Stewart J A How reliable is the morphological diagnosis of penile ulcerations? Sex Transm Dis 1977; 4: 150-152.

4. Nsanze H, Fast M V, d'Costa L J, Tukei P, Curran J, Ronald A Genital ulcers in Kenya. Clinical and laboratory study. Br J Vener Dis $1981 ; 57: 378-381$.

5. Denys G A, Chapel T A, Jeffries C D An indirect fluorescent antibody technique for Haemophilus ducreyi. Health Lab Sci 1978; 15: 128-132.

6. Hansen E J, Loftus T A Monoclonal antibodies reactive with all strains of Haemophilus ducreyi. Infect Immun 1984; 44: 196-198.

7. Hammond G W, Lian J C, Wilt J C, Ronald A Comparison of specimen collection and laboratory techniques for isolation of Haemophilus ducreyi. J Clin Microbiol 1978; 7: $39-43$.

8. Kohler G, Milstein C Derivation of specific antibodyproducing tissue culture and tumor lines by cell fusion. Eur J Immunol 1976; 6: 511-519.

9. Barenkamp S J, Munson R S, Granoff D M Subtyping isolates of Haemophilus influenzae type $\mathrm{b}$ by outermembrane protein profiles. J Infect Dis 1981 ; 143: 668676. transmission of HIV infection. ${ }^{18}$ The availability of specific reagents for the rapid detection of $H$. ducreyi in clinical material could be of great value. We have started to investigate the MAbs described here as diagnostic reagents. We also hope to use them and the antigens they define as tools for studying the pathogenesis of chancroid.

We thank Drs I. N. Brown and C. A. Ison for help with MAb production and other technical aspects of this study, Professor P. Piot (Belgium), Dr Y. F. Ngeow (Malaysia), Dr D. Dance (Thailand), Dr R. Ballard (S. Africa) and Dr J. A. Odumeru (Canada) for kindly donating strains of $H$. ducreyi. This study was supported by the North West Thames Regional Health Authority under the Locally Organized Research Scheme.

10. Odumeru J A, Ronald A R, Albritton W L Characterization of cell proteins of Haemophilus ducreyi by polyacrylamide gel electrophoresis. J Infect Dis 1983; 148: 710-714.

11. Lowrey O H, Rosebrough N J, Farr A L, Randall R J Protein measurement with the folin phenol reagent. $J$ Biol Chem 1951; 193: 265-275.

12. Laemmli U K. Cleavage of structural proteins during the assembly of the head of bacteriophage $\mathrm{T}_{4}$. Nature 1970 ; 227: 680-685.

13. Schalla W O, Sanders L L, Schmid G P, Tam M R, Morse $S$ A Use of dot-immunoblotting and immunofluorescence assays to investigate clinically suspected cases of chancroid. J Infect Dis 1986; 153: 879-887.

13. Towbin H, Staehelin T, Gordon J Electrophoretic transfer of proteins from polyacrylamide gels to nitrocellulose sheets: procedure and some applications. Proc Natl Acad Sci USA 1979; 76 : 4350-4354.

15. Ison C A, Harvey D G, Tanna A, Easmon C S F Development and evaluation of scheme for serotyping. Gardnerella vaginalis. Genitourin Med 1987; 63: 196201.

16. Stephens R S, Kuo C C, Tam M R Sensitivity of immunofluorescence with monoclonal antibodies for detection of Chlamydia trachomatis inclusions of cell culture. J Clin Microbiol 1982; 16: 4-7.

17. Ison $\mathrm{C} \mathrm{A}, \mathrm{McLean} \mathrm{K}$, Gedney $\mathrm{J}$ et al Evaluation of direct immunofluorescence test for diagnosing gonorrhoea. $J$ Clin Pathol 1985; 38 : 1142-1145.

18. Piot $\mathbf{P}$, Laga $\mathbf{M}$ Genital ulcers, other sexually transmitted diseases and the sexual transmission of HIV. Br Med J $1989 ; 298$ : 623-624. 